\title{
Antimicrobial activity and antibiotic sensitivity of three isolates of lactic acid bacteria from fermented fish product, Budu
}

\author{
Liasi, S. A., ${ }^{1}$ Azmi, T. I., ${ }^{2}$ Hassan, M. D., ${ }^{3}$ Shuhaimi, M., ${ }^{4}$ Rosfarizan, M. ${ }^{1}$ and Ariff, A. B. ${ }^{1 *}$ \\ ${ }^{1}$ Department of Bioprocess Technology, Faculty of Biotechnology and Biomolecular Science, Universiti Putra Malaysia, \\ 43400 UPM Serdang, Selangor. ${ }^{2}$ Department of Veterinary Clinical Studies, Faculty of Veterinary Medicine, Universiti \\ Putra Malaysia, 43400 UPM Serdang, Selangor. ${ }^{3}$ Department of Veterinary Preclinical Sciences, Faculty of Veterinary \\ Medicine, Universiti Putra Malaysia, 43400 UPM Serdang, Selangor. ${ }^{4}$ Department of Microbiology, Faculty of \\ Biotechnology and Biomolecular Science, Universiti Putra Malaysia, 43400 UPM Serdang, Selangor.
}

E-mail:arbarif@biotech.upm.edu.my

Received 23 December 2008; received in revised form 7 February 2009; accepted 7 February 2009

\begin{abstract}
Three isolates of lactic acid bacteria (LAB) from the fermented food product, Budu, were identified as genus lactobacillus (Lactobacillus casei LA17, Lactobacillus plantarum LA22 and L. paracasei LA02), and the highest population was Lb. paracasei LA02. The antibacterial agent produced by the isolates inhibited the growth of a range of gram-positive and gram-negative microorganisms. Antimicrobial sensitivity test to 18 different types of antibiotic were evaluated using the disc diffusion method. Inhibition zone diameter was measured and calculated from the means of five determinations and expressed in terms of resistance or susceptibility. All the LAB isolates were resistant to colestin sulphate, streptomycin, amikacin, norfloxacin, nalidixic acid, mecillinam, sulphanethoxazole/ trimethoprim, kanamycin, neomycin, bacitracin and gentamycin but susceptible to erythromycin, penicillin G, chloramphenicol, tetracycline, ampicillin and nitrofurantion.
\end{abstract}

Keywords: Lactic acid bacteria, antimicrobial activity, antibiotic sensitivity, fermented fish product, inhibition zone

\section{INTRODUCTION}

"Antimicrobial agent" is a general term used to refer to any compound which include antibiotics, food antimicrobial agents, sanitizers, disinfectants, and other substances that acts against microorganisms. Antibiotics, on the other hand are antimicrobial agents produced by bacteria, fung or of synthetic in nature. Antibiotic resistance refers to the ability of microorganisms to withstand the bacteriostatic and bactericidal effects of antibiotics. It provides a survival benefit to the invading microorganisms and under such circumstances it is difficult to eliminate the infection caused by these microorganisms. The mechanisms by which microorganisms exhibit resistance to antibiotics include drug inactivation or modification, alteration of target site, alteration in the metabolic pathway, and reduced drug accumulation (Katzung, 2004). The development of antibiotic resistance in bacteria is of public concern in view of the fact that a patient could develop antibiotic resistance by contacting a resistant microorganism or the emergence of a microorganism in the patient's body when treatment with antibiotic begins (Nagulapally, 2007).

Antimicrobials have been used increasingly as a primary intervention for inhibition or inactivation of pathogenic microorganisms in foods (Davidson and Zivanovic, 2003). Generally, food antimicrobial agents are not used alone to control foodborne pathogens, but are included as components of the multiple approaches to microbial control. Lactic acid bacteria (LAB) from fermented products may act as a reservoir of antimicrobial-resistance genes that could be transferred to pathogens, either in the food web or, more importantly, in the gastrointestinal tract of human and animal (Belén Flórez et al., 2005). However, there are different views pertaining to the resistance susceptibility breakpoints of most antimicrobials in LAB (Charteris et al., 2001; Danielsen and Wind, 2003). Distinguishing the intrinsic, nonspecific, and acquired resistance is difficult as it requires antimicrobial-resistance patterns of many $L A B$ species (Teuber et al., 1999).

The present study was undertaken to determine the antimicrobial activity and antibiotic susceptibility of three isolates of $L A B$ from a Malaysian fermented fish product, known as Budu. Being delicacy to a sector of the Malaysian population, this fermented food product is commercially available and information obtained from this study could contribute to the potential use of these LAB isolates in the food and pharmaceutical industries.

\section{MATERIALS AND METHODS}

\section{Source of sample}

The fermented fish product, Budu, manufactured by a small scale domestic factory in Kota Baharu, Kelantan,

\section{${ }^{*}$ Corresponding author}


Malaysia was used as the source for isolation. This fermented product was prepared from marine fries, Stolephorus genera. The fries were mixed with tamarind and coconut sugar in salt solution (15\%) and then fermented at room temperature in large earthen ware pots. The ratio between fries and salt solution was $1: 2$. Samples for the isolation were taken directly from the pots after 6 months of fermentation. All samples were kept refrigerated, so that their microbial load did not change during storage, and processed between 2 to $8 \mathrm{~h}$ after the collection.

\section{Isolation of lactic acid bacteria}

At first, $25 \mathrm{~mL}$ of sample was mixed with $225 \mathrm{~mL}$ of buffered peptone water (BPW, Oxoid) to obtain a 1:10 dilution. Serial dilutions of the samples were prepared in $0.1 \%$ peptone water. MRS agar was supplemented with $0.01 \%$ sodium azide to inhibit the growth of gram-negative bacteria. The diluted sample was streaked on the MRS agar plates and then incubated anaerobically for $24 \mathrm{~h}$.

The stock cultures of $L A B$ and the indicator microorganisms were maintained in MRS broth or nutrient broth supplemented with $15 \%$ glycerol and stored at $80^{\circ} \mathrm{C}$. Working cultures were prepared as slants on MRS agar for $L A B$ or nutrient agar supplement for the indicators and stored at $4{ }^{\circ} \mathrm{C}$. Prior to its use in experiments the $L A B$ cultures were transferred twice into the appropriate medium. API $50 \mathrm{CHL}$ stripes were used to identify all isolates to species level. Bacterial cells were inoculated according to procedures as recommended by the manufacturer. The APIs were incubated at $37^{\circ} \mathrm{C}$ and reactions were observed after $48 \mathrm{~h}$. The API database (Biomerieux SA) and accompanying computer software were used to interpret the data obtained.

\section{Morphological, physiological and biochemical examination of $L A B$}

The morphological, physiological and biochemical examination of the isolates were determined by the standard procedure of gram staining, catalase test and gas production test.

\section{Determination of antibiotic susceptibility}

Pure culture colonies of $L A B$ were inoculated in MRS broth at $37^{\circ} \mathrm{C}$ for $24 \mathrm{~h}$. A sterile cotton wool swab dipped into the bacterial suspension was spread evenly on the surface of the MRS agar plate. The inoculated plate was allowed to dry before placing the diffusion discs containing antibiotics.

Susceptibility of the three isolates to 18 types of antibiotics was performed by the disc diffusion method as described by Bauer et al. (1966). Using commercially available antibiotics disc (Oxide) containing penicillin $\mathrm{G}(2$ Units), ampicillin $(25 \mu \mathrm{g})$, erythromycin $(10 \mu \mathrm{g})$, colestin sulphate $(10 \mu \mathrm{g})$, streptomycin $(10 \mu \mathrm{g})$, amikacin $(30 \mu \mathrm{g})$, norfloxacin $(10 \mu \mathrm{g})$, chloramphenicol $(30 \mu \mathrm{g})$, tetracycline $(10 \mu \mathrm{g})$, nalidixic acid $(30 \mu \mathrm{g})$, gentamycin $(30 \mu \mathrm{g})$, mecillinam (25 $\mu \mathrm{g})$, nitrofurantion $(300 \mu \mathrm{g})$, sulphanethoxazole/ trimethoprim $(25 \mu \mathrm{g})$, vancomycin (30 $\mu \mathrm{g})$, bacitracin $(10 \mu \mathrm{g})$, kanamycin $(30 \mu \mathrm{g})$, neomycin $(30$ $\mu \mathrm{g})$ were placed on the surface of the agar plates. Precaution was taken to ensure that there was uniform contact between the antibiotic disc and agar plate. The plates were then incubated at $37^{\circ} \mathrm{C}$ for $24 \mathrm{~h}$.

Inhibition zone diameters were measured inclusive of the diameter of the discs. Results were expressed as sensitive, $S(\geq 21 \mathrm{~mm})$; intermediate, I (16-20 mm) and resistant, $R(\leq 15 \mathrm{~mm})$, respectively according to that described by Vlková et al., (2006).

\section{Assay for antimicrobial agent}

Cell-free culture supernatants for antibacterial assay was prepared by growing the isolates in MRS broth at $37^{\circ} \mathrm{C}$ and centrifuged at $12,000 \times g$ for $10 \mathrm{~min}$ at $4{ }^{\circ} \mathrm{C}$. The antimicrobial activity of the cell-free culture supernatant was determined by the agar well diffusion assay according to the method by Tagg et al. (1976). Aliquots of supernatants $(100 \mu \mathrm{L})$ were placed in wells $(6 \mathrm{~mm}$ diameter) cut in cooled soft nutrient agar plates $(25 \mathrm{~mL})$ previously seeded $(1 \% \mathrm{v} / \mathrm{v})$ with the appropriate indicator strains. The plates were incubated under optimal conditions for growth of the target microorganisms. After $24 \mathrm{~h}$, diameters of the growth inhibition zones were measured. The inhibitory spectrum of the antibacterial agent produced by isolates of lactobacilli against different gram-positive and gram-negative bacteria was determined by agar-well diffusion assay.

\section{RESULTS}

From the morphological examination, all isolates were gram positive and short chain bacilli. The isolates were catalase negative, facultative anaerobes, negative to the production of gas from glucose and growth was totally inhibited at $5{ }^{\circ} \mathrm{C}$ and $45^{\circ} \mathrm{C}$ (Table 1). Based on these characteristics and on the basis of the API $50 \mathrm{CHL}$ carbohydrate fermentation profiles, the isolates were phenotypically identified as $L b$. casei $L A 17, L b$. plantarum LA22 and Lb. pracasei LA02.

Results of the sensitivity studies of the LAB isolates tested against 18 different types of antimicrobial agents are shown in Table 2. All isolates were susceptible to $B$ lactam group of antibiotic which include penicillin $G$ and ampicillin. The isolates were also susceptible to erythromycin, chloramphenicol, nitrofurantion and tetracycline. In addition, all isolates were also resistant to a large number of aminoglycosides, which include amikacin, kanamycin, neomycin, streptomycin and gentamycin. Furthermore, all isolates were also resistant to the following groups of antimicrobial agents: tetracyclines (tetracycline), quinolones (nalidixic acid and norfloxacin), sulfonamides (sulphanethoxazole), colestin sulphate and mecillinam. Results from this study also showed that $L b$. paracasei LA02 was resistant to vancomycin while $L$ b. plantarum LA22 and Lb. casei LA17 were susceptible to vancomycin. 
Table 1: Morphological, physiological and biochemical characteristics of the LAB isolated from fermented fish product, Budu

\begin{tabular}{|c|c|c|c|c|}
\hline \multirow[t]{2}{*}{ Characteristics } & \multicolumn{3}{|c|}{ LAB isolates } & \multirow[b]{2}{*}{ Lb. plantarum LA22 } \\
\hline & & Lb. paracasei LA02 & Lb. casei LA17 & \\
\hline Cell morphology & & Bacilli & Short bacilli & Short bacilli \\
\hline Gram stain reaction & & + & + & + \\
\hline Colony morphology & & $\begin{array}{llr}\text { Circle, } & \text { white } & \text { to } \\
\text { creamish } & (0.5 \text { to } 1.8 \\
\mathrm{mm}) & \end{array}$ & $\begin{array}{l}\text { Circle } \\
(1 \mathrm{~mm})\end{array}$ & $\begin{array}{l}\text { Circle, creamish to } \\
\text { whitish ( } 0.3 \text { to } 0.5 \\
\mathrm{~mm})\end{array}$ \\
\hline Catalase activity & & - & - & - \\
\hline Glucose fermentation & & + & + & + \\
\hline Growth at extreme & $5^{\circ} \mathrm{C}$ & - & - & - \\
\hline temperatures & $45^{\circ} \mathrm{C}$ & - & - & - \\
\hline Gas production & & - & - & - \\
\hline
\end{tabular}

Table 2: Assessment of three strains of LAB to 18 different types of antibiotics

\begin{tabular}{|c|c|c|c|c|c|c|c|}
\hline $\begin{array}{l}\text { Antimicrobial } \\
\text { agents }\end{array}$ & 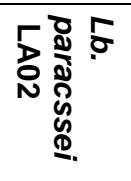 & 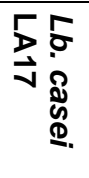 & 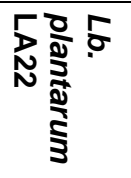 & Antimicrobial agents & 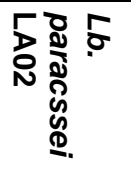 & 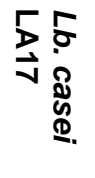 & 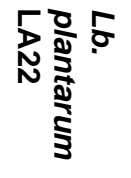 \\
\hline B-lactam & & & & Aminoglycosides & & & \\
\hline$\overline{\text { Penicillins }}$ & & & & amikacin & +++ & +++ & +++ \\
\hline penicillin G & + & + & + & kanamycin & +++ & +++ & +++ \\
\hline ampicillin & + & + & + & neomycin & +++ & +++ & ++ \\
\hline Peptides & & & & streptomycin & +++ & +++ & +++ \\
\hline Glycopeptide & & & & gentamycin & +++ & +++ & ++ \\
\hline vancomycin & +++ & + & + & Tetracyclines & & & \\
\hline Polypeptides & & & & tetracycline & + & + & + \\
\hline bacitracin & ++ & +++ & +++ & Quinolones & & & \\
\hline Macrolides & & & & $\overline{\text { nalidixic acid }}$ & +++ & +++ & +++ \\
\hline $\begin{array}{l}\text { erythromycin } \\
\text { Fenicols }\end{array}$ & + & + & + & $\begin{array}{l}\text { norfloxacin } \\
\text { Sulfonamides }\end{array}$ & +++ & +++ & +++ \\
\hline chloramphenicol & + & + & + & $\begin{array}{l}\text { sulphanethoxazole/ } \\
\text { trimethoprim }\end{array}$ & +++ & +++ & +++ \\
\hline Nitrofurantoin & & & & Others & & & \\
\hline nitrofurantion & + & + & + & $\begin{array}{l}\text { colestin sulphate } \\
\text { mecillinam }\end{array}$ & $\begin{array}{l}+++ \\
+++\end{array}$ & $\begin{array}{l}+++ \\
+++\end{array}$ & $\begin{array}{l}+++ \\
+++\end{array}$ \\
\hline
\end{tabular}

Table 3: Inhibitory spectrum of selected strains of antibacterial-producing LAB on gram-positive and gram-negative bacteria

\begin{tabular}{|c|c|c|c|c|c|}
\hline \multirow[b]{2}{*}{ Indicator species } & \multirow[b]{2}{*}{ train } & \multirow[b]{2}{*}{ Source } & \multicolumn{2}{|c|}{ Activities (mm) } & \multirow[b]{2}{*}{$\begin{array}{l}\text { Lb. plantarum } \\
\text { LA22 }\end{array}$} \\
\hline & & & $\begin{array}{l}\text { Lb. paracasei } \\
\text { LA02 }\end{array}$ & $\begin{array}{l}\text { Lb. casei } \\
\text { LA1 } \\
7\end{array}$ & \\
\hline B. cereus & $\begin{array}{r}1 \\
1778\end{array}$ & ATCC & +++ & +++ & +++ \\
\hline S. aureus & $5923^{2}$ & ATCC & +++ & +++ & +++ \\
\hline Salmonella enterica & $331^{1}$ & ATCC & +++ & +++ & +++ \\
\hline Listeria monocytogenes & $5313^{1}$ & ATCC & +++ & +++ & ++ \\
\hline $\begin{array}{l}\text { E. coli } \\
\text { Lactococcus lactis }\end{array}$ & - & $\begin{array}{l}\text { UPM } \\
\text { ATCC }\end{array}$ & $\begin{array}{l}+++ \\
+++\end{array}$ & $\begin{array}{l}+++ \\
+++\end{array}$ & $\begin{array}{l}++ \\
+\end{array}$ \\
\hline
\end{tabular}


Degree of inhibition: $\quad+\quad=$ Moderate inhibition zone $(6-9 \mathrm{~mm}) ;++=$ Strong inhibition zone $(10-14 \mathrm{~mm})$ $+++=$ Very strong inhibition zone (15-18mm); - = No inhibition zone

All isolates have ability to produce antibacterial agents (Table 3 ). Lb. paracasei LA02 and Lb. casei LA17 produced about the same amount of antibacterial agent, and higher than that produced by Lb. plantarum LA22. The inhibitory spectrum of the antibacterial agent produced by selected isolates of Lactobacilli against different gram-positive and gram-negative bacteria was determined by agar- well diffusion assay. Table 3 also shows the antagonistic effect of the antibacterial agent on the growth of other gram-positive and gram-negative pathogenic microorganisms. All isolates studied, demonstrated an inhibitory effect on E. coli, Listeria monocytogenes, Salmonella enterica, Staphylococcus aureus and Bacillus cereus. The antibacterial agents reported here are expected to be peptidic antibacterial agent such as bacteriocin. However, identification and characterization of these antibacterial agents are being carried out in our laboratory.

\section{DISCUSSION}

To date, knowledge on the susceptibility of LAB to antimicrobial agents is rather limited in view of the large numbers of genera and species encountered in this group of bacteria apart from variances in the resistance spectra (Ocana et al., 2006). Transfer of resistance to antimicrobial agents is an essential mechanism if the $\mathrm{LAB}$ are to adapt and survive in specific environment (Herreros et al., 2005). Hence in view of the above, before a strain of LAB can be used as a feed additive it must undergo antibiotic resistance screening to ensure its safe application.

Relatively few microorganisms are able to grow in Budu due to reduced oxygen level, low $\mathrm{pH}$ and very high salt content. Reports on the isolation and identification of $\mathrm{LAB}$ from Budu are very limited in the literature. Ohhira (1990) reported that 14 strain of Lactobacillus plantarum and 1 strain of Streptococcus faecalis have been isolated from Budu. In this study, three LAB strains have been isolated from Budu. The susceptibility of these LAB isolates tested against 18 different types of antimicrobial agents in the present study showed that they are susceptible to the B-lactam group of antibiotics (penicillin $G$ and ampicillin) and other principal types of antibiotics which include erythromycin, chloramphenicol, nitrofurantion and tetracycline. This finding is contrary to previous reports which stated that $L A B$ are normally resistant to the principle types of antibiotics (Halami et al., 2000). B-lactam which are bactericidal, became the most widely used therapeutic class of antimicrobial agent because of their broad antibacterial spectrum and excellent safety profile. They inhibit bacteria cell wall synthesis and have a lethal effect on gram-positive bacteria. Erythromycins belong to macrolides group and have similar range of action and efficacy similar to that of penicillin. This group of antibiotics binds to ribosome, blocks protein synthesis (bacteriostatic) and are effective against gram-positive microorganisms (selectively accumulated compared with gram negatives).

From the 18 antimicrobial agents tested against, the three LAB isolates were resistant to 11 different types of antimicrobial agents. Most evident was the resistant to the aminoglycosides, sulfanamides and quinolones groups of antimicrobial agents. Aminoglycosides work by impeding the protein formation of bacteria in invading cells and are effective against a wide variety of bacteria and other microorganisms and are believed to prevent the production of proteins in the invading bacterial cell in this group. Bacterial resistance to aminoglycosides can result from mutations affecting the ribosomes and from changes in cellular permeability, but the most important cause of resistance is enzymically catalyzed inactivation of the antibiotics (Franklin and Snow, 2005).

Unfortunately, bacterial resistance to sulfonamides often coexists with trimethoprim resistance. Sulfonamide resistance could be due either to mutation in the chromosomal gene that mediates dihydropteroate synthesis, or to the acquisition of plasmid-borne genes coding for sulfonamide-resistant forms of the enzyme (Franklin \& Snow, 2005). Amongst the antibiotics, vancomycin, an inhibitor of cell wall synthesis is of major concern as it is one of the last antibiotics broadly effective against clinical infections caused by multi-drug resistance pathogens (Johnson et al., 1990). Lb. casei LA17 and Lb. plantarum LA22 were vancomycin sensitive in contrast to $L b$. paracasei LA02.

All LAB isolates in this study showed that they are resistant to gram-negative spectrum antibiotic (nalidixic acid) and aminoglycoside antibiotics (amikacin, kanneomycin, neomycin and streptomycin). These findings concur with those reported by Zhou et al., (2005) and Termerman et al. (2003) who claimed that most Lactobacillus, Enterococcus and Pediococcus strains used as probiotic were resistant to gram-negative spectrum and aminoglycoside antibiotics. Resistance of these antibiotics is usually intrinsic meaning that it is not transferring the genes to pathogenic or bacterial flora (Ammor et al., 2007).

Research on antimicrobial substances produced by $\mathrm{LAB}$, has led to their potential use as natural preservatives. These antibacterial compounds may be used to combat the growth of pathogenic microorganisms in the food industry. Antimicrobial compounds can be applied either as purified chemical agents or as viable cultures in the case of fermented products (Barnby-Smith, 1992). Novel purified antimicrobial compounds require convincing data to substantiate their lack of toxicity to ensure their acceptance before use in various food processes. 


\section{REFERENCES}

Ammor, M. S., Belén Flórez, A. and Mayo, B. (2007). Antibiotic resistance in non- enterococcal lactic acid bacteria and bifidobacteria. Food Microbiology 24, 559-570.

Barnby-Smith, F. M. (1992). Bacteriocins: applications in food preservation. Trends in Food Science and Technology 3, 133-137.

Bauer, A. W., Kirby, W. M. M., Sherris, J. C. and Turck, M. (1966). Antibiotic susceptibility testing by a standardized single disk method. American Journal of Clinical Pathology 45, 493-496.

Belén Flórez, A., Delgado,S. and Mayo, B. (2005). Antimicrobial susceptibility of lactic acid bacteria isolated from a cheese environment. Canadian Journal of Microbiology 51, 51-58.

Charteris, W. P., Kelly, P. M., Morelli, L., and Collins, J. K. (2001). Gradient diffusion antibiotic susceptibility testing of potentially probiotic lactobacilli. Journal of Food Protection 64, 20072014.

Danielsen, M., and Wind, A. (2003). Susceptibility of Lactobacillus spp. to antimicrobial agents. International Journal of Food Microbiology 82, 1-11.

Davidson, P. M. And Zivanovic, S. (2003). Food antimicrobials. In: Davidson, P. M., Sofos, J. N. and Branen. A. L. Antimicrobials in foods.: CRC press, USA.

Franklin, T. J. and Snow, G. A. (2005). Biochemistry and Molecular Biology of Antimicrobial Drug Action. Springer. New York, USA.

Herreros, M. A., Sandoval, H., González, L., Castro, J. M., Fresno, J. M. and Tornadijo, M. E. (2005). Antimicrobial activity and antibiotic resistance of lactic acid bacteria isolated from Armada cheese (a Spanish goats' milk cheese). Food Microbiology 22, 455-459.

Halami, P. M., Chandrashekar, A. and Nand, K. (2000). Lactobacillus farciminis MD, a newer strain with potential for bacteriocin and antibiotic assay. Letters of Applied Microbiology 30, 197-202.

Johnson, A. P., Uttley, A. H. C, Woodford. N. and George, R. C. (1990). Resistance to vancomycin and teicoplanin: an emerging clinical problem. Clinical Microbiology Reviews 3, 280-291.

Katzung, B. G. (2004). Basic and Clinical Pharmacology, Lange Medical Books, McGraw-Hill, 9th edition, New York, USA.

Nagulapally, S. R. (2007). Antibiotic resistance patterns in municipal wastewater bacteria. M.Sc. Thesis. Kansas State University, Manhattan, Kansas, USA.

Ocana, V., Silva, C. and Nader- Macias, M. E. (2006). Antibiotic Susceptibility of Potentially Probiotic Vaginal Lactobacilli. Hindawi publishing cooperation, Argentina.

Ohhira, I. (1990) Isolation and identification of lactic acid bacteria from traditional fermented sauce in Southeast Asia. Japanese Journal of Dairy and Food Science 39, 17-23.
Temmerman, R., Pot, B., Huys, G. and Swings, J. (2003). Identification and Antibiotic Susceptibility Of Bacterial Isolates From Probiotic Products. International Journal of Food. Microbiology 81, 1-10.

Teuber. M., Melile. L. and Schwarz. F. (1999). Acquired antibiotic resistance in lactic acid bacteria from food. Antonie van Leeuwenhoek 76, 115-137.

Tagg, T. R., Dajani, A.S. and Wannamaker, L. W. (1976). Bacteriocin of Gram-positive bacteria. Bacteriology Review 40, 722-756.

VIková, E., Rada, V., Popelářová, P., Trojanová, I. and Killer, J. (2006). Antimicrobial susceptibility of bifidobacteria isolated from gastrointestinal tract of calves. Livestock Science 105, 253-259.

Zhou, J. S., Pillidge, C. J., Gopal, P. K. and Gill, H. S. (2005). Antibiotic Susceptibility Profiles of New Probiotic Lactobacillus and Bifidobacterium strains. International Journal of Food Microbiology 98, 211217. 